\title{
Reconciling Pan-Arabism and Pan-Africanism: The North African Leadership Dilemma

\author{
Radwa Saad*
}

\begin{abstract}
The purpose of this research to examine the challenges Arab leaders face in simultaneously adhering to Pan-Arabism and Pan-Africanism and extract conditions in which the two ideologies can be reconciled to produce mutual benefits. This study poses the question: what strategies do North-African leaders deploy to balance their Pan-Arab and Pan-African commitments and what repercussions do these strategies have on the state of Arab-African relations? By drawing on two scenarios where Pan-Arabism and PanAfricanism conflicted, namely the 1967-1979 Arab-Israeli Conflict and the 2011 Libyan civil war, it will highlight the role leadership can play in mediating such tensions. The study finds that it is only through the decrease of hegemonic pursuits and the increase in effective leadership processes both domestically and regionally that the two ideologies can coexist.
\end{abstract}

\section{Introduction}

North-African leaders have been highly instrumental in shaping and advancing both Pan-Arabism and Pan-Africanism. Pan-Arabism is best defined as efforts to achieve one single political and economic unity that serves the higher interests of Arab states and populations. The ideology was instrumental in shaping post-colonial state-building process in North Africa and has led to the construction of the League of Arab States (LAS). Similarly, Pan-Africanism, best defined as the determination to promote unity, solidarity, cohesion and cooperation among the peoples of Africa and African States', has led to the development of the Organization of African Union (OAU) and its successor the African Union (AU). ${ }^{1}$ Adherence to both ideologies has bestowed North-African leaders with diverging aspirations and commitments. A common policy that serves the higher interests of Arabs can be incompatible with a common policy transcending race, ethnicity, and religion to serve the interests of the African continent.

Wedged between their Pan-Arab and Pan-African commitments, NorthAfrican leaders have struggled to demonstrate a genuine commitment to African affairs. At best, they are viewed as gateways to wider alliances

${ }^{1} \mathrm{AU}$ (2000), Constitutive Act of the African Union. Available at: https://au.int/sites/default/files/pages/32020-file-constitutiveact en.pdf (Accessed: 28 March 2019) 
outside the African continent, particularly the Middle East and parts of Asia. ${ }^{2}$ At worse, they are perceived as a homogenous entity with ongoing 'family quarrels' utilizing Sub-Saharan Africa (SSA) as a geographic arena to contest their ideological rivalries through the manipulation of conflicts and political processes. ${ }^{3}$ This claim is often supported by the reality that in almost every state where Arab and African identities intermingle, conflict is ripe. The Arab-African politics behind the protraction of the civil war in Somalia, the conflict between North and South Sudan, the enslavement of black Africans in Mauritania and the general discrimination against African minorities in predominantly Arab states, all give weight to the claim that Afro-Arab unity is a fallacy. Whereas a clear tension between Arab and African identities persists throughout Africa, it is often overlooked and understudied by scholars. There remains a need to deconstruct the nature of Afro-Arab relations and investigate under what conditions Arab and African interests can be synchronized. Such understandings can enhance cooperation within the African continent by allowing North-African leaders to engage in more constructive and defined relations with the remainder of the continent.

The purpose of this study is to examine the challenges that Arab leaders face in adhering to Pan-Arabism and Pan-Africanism simultaneously and to extract conditions in which the two ideologies can be reconciled to produce mutual benefits. It poses the following question: what strategies do NorthAfrican leaders deploy to balance their Pan-Arab and Pan-African commitments and what repercussions do these strategies have on the state of Arab-African relations? Central to this research is the distinction between leadership and hegemony, which is often overlooked and conflated in much of the existing literature. A leadership approach is adopted to examine the relational dynamics and processes of interactions existent between NorthAfrican and Sub-Saharan-African states.

There are many complexities implicated in defining what constitutes an 'Arab' and an 'African' especially as the Arabic language is spoken in states North and South of the Sahara. However, this study does not endeavour to

\footnotetext{
${ }^{2}$ See for example Akinsanya, Adeoye (1980), 'The Afro-Arab Alliance: A Dream or Reality?', Journal of the Historical Society of Nigeria 10(2), pp. 87-104; Salem, Ahmed (2011), 'The Myth and Reality of the North Africa versus Sub-Saharan Split in the Nile Basin' in Regional Integration in Africa Bridging the North-Sub-Saharan Divide ed: Hassan Hamdy (African Books Collective); and Sharawy, Helmy (2014), 'Arab-African relations from Liberation to Globalisation', African Renaissance 1(1), pp. 43-54

3 See for example: Wai, Dunstan (1983), 'African-Arab Relations: Interdependence or Misplaced Optimism?', The Journal of Modern African Studies 21(02), pp. 187-213; Bankie, Bankie Forster and Mchombu, Kingo (2008), Pan-Africanism/African nationalism: strengthening the unity of Africa and its diaspora (Red Sea Press); Gordan, Murray (1998) Slavery in the Arab World (New Amsterdam Books)
} 
deconstruct what is Arab or African, but rather to engage Pan-Arabism and Pan-Africanism as ideologies that espouse certain narratives of identities and examine the role of leadership in operationalizing those narratives. When ascribing to Pan-Arabism, one can automatically assume the presence of an Arab identity and interests and likewise with PanAfricanism. To this end, this sample group selected are the six North-African states that were most affected by the construction and evolution of PanArabism, namely Egypt, Algeria, Tunisia, Libya, Morocco and Sudan. Other countries with an Arab speaking population are excluded due to such states being largely absent from the historical processes that shaped the formation of Pan-Arabism.

This study uses a descriptive multiple case study design to examine the relational dynamics embedded in two events where Pan-Arab and PanAfrican interests conflicted: the Arab-Israeli conflict (1967-1979) and the Libyan Civil War (2011). The 'two-tail' cases selected demonstrate how differences in processes can result in variant outcomes in the phenomena of Pan-Arab and Pan-African relations. ${ }^{4}$ The first case resulted in a convergence of interests and solidarity among the two parties as the ArabIsraeli conflict was transformed from an 'Arab national security issue' into an African one within the context of the OAU. The second case resulted in a divergence of Pan-Arab and Pan-African interests that contributed to the rise and protraction of the Libyan Civil War. By drawing on primary sources such as published reports, newspaper articles, NGO data and the ideological pamphlets of Arab leaders, among others, and a range of secondary sources including academic texts and journals, the study aims to provide a more nuanced, comprehensive and contemporary account of Arab-African relations.

\section{Leadership, Hegemony \& Power}

Examination of Arab-African relations have often been leader-centric. Nasser's success in combating imperialism, Gaddafi's role in the construction of the $\mathrm{AU}$ and Ben Bella's support for liberation movements across the continent are cited as successful examples of leadership. Leadership, however, is not merely the presence or absence of admirable acts executed by a person occupying a position of power as often conceptualized in popular narratives. Rather, it is the relational dynamics governing leaders and followers. The ways in which 'leadership' is

\footnotetext{
${ }^{4} \mathrm{~A}$ two-tail design is whereby cases of extreme variant outcomes in relation to a specific phenomenon (in this case pan-African and pan-African conflict of interest) are deliberately chosen to expose theoretical conditions and/or replications. See for example Yin, Robert K (1984), Case Study Research, Design and Methods (Sage Publications)
} 
described in inter-state relations has been reductionist and misleading, whereby leadership and hegemony are erroneously conflated and used interchangeably. Conceptualizing the difference between these concepts can provide a better understanding of the nature of Afro-Arab relations.

Hegemony is a form of dominance in which a hegemon sways subordinates to achieve its strategic interests using distinct but mutually reinforcing forms of power. ${ }^{5}$ It relies on a delicate balance between overt and covert forms of power, between compulsion and consensus, and between the securitization of a hegemon's interests and the interests of weaker states. ${ }^{6}$ French \& Raven identified five bases of power that are useful and relevant to both discussions on hegemony and leadership:

1. Expert power-> based on B's perception of A's competence.

2. Referent power-> based on B's liking or identification with A.

3. Reward power-> depends on A's ability to provide rewards for $B$.

4.Coercive power-> based on B's perception that A can impose penalties for noncompliance.

5. Legitimate power-> based on internalized values dictating that $A$ has the legitimate right to influence $B$ and that $B$ has an obligation to accept $A$ 's influence. $^{7}$

Based on the extent in which ideational - the shaping of norms and values among subordinate states - and material sources of power are at the forefront of a hegemon's actions, three types of hegemony can be identified. Hard hegemony deploys coercion, threats, political pressure and, to a lesser degree, inducements to assert influence over secondary states. Intermediate hegemony is anchored around the provision of material rewards to subordinate states to change their behaviours. Soft hegemony relies solely on 'normative persuasion' to alter and reconstruct the norms and values of subordinate states. ${ }^{8}$ Through a process of socialization and ideological persuasion, 'the hegemon gains legitimacy through the osmosis of norms and values from dominant to secondary elites. ${ }^{9}$ Soft hegemony is, in many ways, closely related to leadership.

\footnotetext{
${ }^{5}$ Gramsci, Antonio (1995), Further selections from the prison notebooks (University of Minnesota Press)

${ }^{6}$ Hurrell, Andrew (2005), Hegemony and regional governance in the Americas. In Regionalism and Governance in the Americas (Palgrave Macmillan UK), pp. xxix ${ }^{7}$ Raven, Bertram and French, John R. P. (1958), 'Legitimate Power, Coercive Power, and Observability in Social Influence', Sociometry 21 (2), pp. 83-97

8 Destradi, Sandra (2010), 'Regional Powers and Their Strategies: Empire, Hegemony and Leadership', Review of International Studies 36 (4), pp. 903-930

${ }^{9}$ Andrew Fenton, Higgott, Richard and Nossal, Kim Richard (1991), 'Bound to follow? Leadership and Followership in the Gulf Conflict', Political Science Quarterly 106 (3), pp. 398
} 
Leadership, on the other hand, is best defined as 'a process whereby an actor influences a group of individuals to achieve a common goal'. ${ }^{10}$ It is a relational phenomenon examining interactions between leaders and followers. ${ }^{11}$ Viewing leadership as a process allows for a better understanding of the nature of state-society interactions, the perpetual state of change governing societies, the unique historical contexts that allows leaders to emerge in situations and the circumstances that lead to a leader's decline. Northouse has summarized the basic tenants of the leadership process as following:

\section{Leadership is a process.}

2. Leadership involves influence.

3. Leadership occurs within a group context.

4. Leadership involves goal attainment. ${ }^{12}$

If soft hegemony is secured through persuasion as opposed to coercion, how then does it differ from leadership? A clear distinction between hegemony and leadership lies in the end goal desired by the dominant actor. The end goal of hegemony is always the realization of the hegemon's own goals whereas the end goal of leadership is the realization a group's goals. Unlike the one-sided nature of hegemony, leadership relies on the mutual exchange of influence between leaders and follower, resulting in reciprocity. The presence of a common goal allows the transmission of values from leader to followers without condition or stipulation.

There are two ways in which a leader can emerge in regional and domestic politics. The first is whereby a leader directly initiates a socialization process that creates shared norms and values among followers. The leader may consult, explain, persuade or occasionally cajole followers into embodying common goals. The second approach is one where followers initiate the leadership process. In situations where members of a group are too heterogeneous or weak to achieve a collective goal, followers bestow a leader with the responsibility of directing them to their realizations. In this case, the leader need not launch a socialization process, but is merely tasked with bundling the interests of the group in pursuit of their common goal. ${ }^{13}$

The line between hegemony and leadership can be blurred. Power is a function of leadership and hegemony, but its mere presence does not guarantee either. Becoming a hegemon or leader relies on the ability to

\footnotetext{
${ }^{10}$ Northouse, Peter (2015), Leadership: Theory and Practice (Sage publications), p. 6

${ }^{11}$ Grint, Keith (2010), Leadership: A Very Short Introduction (Oxford University Press)

12 Northouse (2015), p. 6

13 Destradi (2010)
} 
convert power to influence. Power facilitates influence but it does not guarantee it (i.e. just because A has more power than B it does not mean that A influences B). ${ }^{14}$ Hegemons are more inclined to coercive and/or reward power while leaders are more inclined to persuasive and referent power. Both leadership and hegemony are not omnipotence, but require skills in decision-making, resource-gathering, utilizing incentives and threats, formulating visions and building coalitions; all of which are relational functions that require an institutionalised context. The fundamental difference, however, remains the end goal. Hegemony results in the securitization of the hegemon's self-interests but may be marketed to followers as communal interests whereas leadership reflects the 'the values and motivations - the wants and the needs, the aspirations and the expectations - of both leader and followers.' 15

When examining power dynamics between North-Africa and SSA, it becomes palpable that power is highly skewed in favour of the former. Up until 2010, all six North-African states ranked within the top ten largest economies in Africa. ${ }^{16}$ African funding of the OAU and AU is largely dependent on North-African contributions. Libya's Gaddafi oftentimes paid the membership fees of less wealthy states, albeit with conditions. Furthermore, Egypt and Algeria have the continent's largest militaries while Morocco, Tunisia and Libya rank among the top ten. ${ }^{17}$ Most NorthAfrican states have also been ideologically influential with regards to combating imperialism and envisaging revolutions. This is evident in the fact that most North-African states managed to secure independence before SSA states, and then offered training and assistance to the latter in their armed liberation struggles.

Up until the events of the Arab spring, most North-African states also enjoyed a level of stability less prevalent in SSA that was seemingly mistaken as a source of power, enabling their influence in regional affairs. However, this view fails to consider that while hegemonic powers can provide security for other states in the region, they are often incapable of doing so for themselves. The multi-layered nature of governance bought about by globalization necessitates that regional hegemons defend their positions in international, regional and domestic arenas simultaneously. A

\footnotetext{
${ }^{14}$ Yukl, Gary A (1981), Leadership in Organizations (Pearson Education India)

${ }^{15}$ Burns, James (1978), Leadership (Harper \& Row, New York), pp. 380-383

${ }^{16}$ World Bank (2011), World Bank Indicators Database Gross domestic product 2010. Available at: https://siteresources.worldbank.org/DATASTATISTICS/Resources/GDP.pdf (Accessed 28 March 2019)

${ }^{17}$ Global Fire Power (2016), African Powers Ranked by Military Strength Ranking. Available at: http://www.globalfirepower.com/countries-listing-africa.asp (Accessed: 28 March 2019)
} 
hegemon cannot depend solely on its regional dominance for its survival and must make major concessions to its domestic population. ${ }^{18}$ According to Putman, hegemons are tasked with influencing separate 'chessboards' in that they must 'strive to reconcile domestic and international imperatives simultaneously' keeping in mind that 'moves that are rational for a player at one board...may be impolitic for that same player at the other board'. ${ }^{19}$ Thus, it becomes vital to differentiate between the pursuit of hegemony and leadership externally and examine how domestic leadership processes influence these pursuits. The tendency to mistake hegemony for leadership and stability for power is what led many to overlook the leadership crisis that produced the 2011 uprisings and dramatically altered regional dynamics. ${ }^{20}$

According to hegemonic stability theory, the presence of a single hegemonic force possessing more power than their counterparts is essential for regional stability. ${ }^{21}$ Subordinate states submit to the hegemon's pursuits out of recognition of their own weakness and their inability to exercise effective opposition. ${ }^{22}$ However, the relatively homogenous power dynamics among North-African states have facilitated a hostile environment whereby multiple states seek hegemonic status, but none are willing to play the subordinating role. Leadership theory provides an alternative to this impasse by suggesting that in the presence of an effective leader, equally powerful states can cooperate and coexist in a state of amity.

In fact, stronger states are more equipped to identify their needs and in turn require less direction, allowing leadership to surface in an easier, more power diffused process. However, this has yet to happen in North-Africa where economic integration is one of the lowest in the world and political integration is scarce despite common political and security challenges. ${ }^{23}$ Contrary to the narrative that Arabs constitute a relatively homogenous entity distinct from the remainder of Africa, the division of Arab states may

\footnotetext{
${ }^{18}$ Warner, Jeroen (2008), 'Contested hydro-hegemony/hydraulic control and security in Turkey', Water Alternatives 1(2), pp. 271-288

${ }^{19}$ Putnam, Robert (1988), 'Diplomacy and Domestic Politics: The Logic of Two-level Games', International Organizations 42 (3), pp. 427-460

${ }^{20}$ El-Mahdi, Rabab and Philip, Marfleet (2009), Egypt: The Moment of Change (Zed Books)

${ }^{21}$ Kindleberger, Charles (1974), The World in Depression 1929-1939 (Berkeley: University of California Press)

${ }^{22}$ Gilpin, Robert (1981), War and Change in World Politics (Cambridge: Cambridge University Press)

${ }^{23}$ Council on Foreign Relations (2012), 'Summary Report for workshop on Regional Cooperation in a New Middle East' Joint report by CFR's International Institutions and Global Governance program and the American University in Cairo's School of Global Affairs and Public Policy
} 
be one of the biggest factors hindering their contributions to PanAfricanism.

\section{Pan-Arab and Pan-African Unity: A Paradox?}

Pan-Arabism is best summarised as the belief in the cultural and political unity of Arab states. It is a corollary of Arab nationalism, the belief that all Arab people share a unique bond based on a shared language, history and religion. It was started by a small class of mobile intellectual elites seeking autonomy from the Ottoman Empire during the early $20^{\text {th }}$ century but reached the peak of its popularity in the 1950's/1960's. Spearheaded by Egyptian President Gamal Abdel Nasser, who quickly became the de facto leader of the Arab word following the 1956 Suez Canal crisis, Arab political elites constructed a plan to solidify a common Arab culture. ${ }^{24}$ Through the penetration of the Arabic language and the use of national broadcasting systems and radio programs, Pan-Arabism became an embedded cultural phenomenon. ${ }^{25}$ As articulated by El Amrani:

'Arab states... put culture at the service of politics (giving rise to such terms as Arab national culture, national identity culture, Islamic identity culture, resistance culture, the ruling party culture and centralized official culture) rather than putting politics at the service of culture.'26

The humiliating defeat of the Arabs in the 1967 Arab-Israeli war, the dissolution of the short-lived United Arab Republic (UAR) in 1971, the feebleness of the LAS and the appallingly low-level of integration among Arab states highlight Pan-Arabism's failure to translate into a viable political project. Nonetheless, its strength as a cultural movement has enabled its resilience despite incessant political defeats. In 2011, the Arab Research Centre published the results of a comprehensive public opinion survey accounting for $80 \%$ of Arabs across 11 states including Egypt, Sudan, Morocco and Algeria. The survey revealed that over $71 \%$ of correspondents still believe in the existence of a united Arab nation, over $81 \%$ could identify threats to 'Arab national security' and $75 \%$ were in favour of adopting

\footnotetext{
${ }^{24}$ Sirriyeh, Hussien (2000), 'A New Version of Pan-Arabism?', Journal of International Relations 15(3), pp. 53-66

${ }^{25}$ See example El Amrani, Issandr (2005), 'Cultural politics and cultural policy in the Arab world' in Cultural Policies in Algeria, Egypt, Jordan, Lebanon, Morocco, Palestine, Syria and Tunisia (Boekmanstudies) and see example Ouidyane, Elouardaoui (2014), Behind the Scenes of Pan-Arabism (Glänta Eurozine)

${ }^{26}$ El Amrani (2005), p. 24
} 
integration formulas to support greater unification. ${ }^{27}$ The cross-border solidarity, coordination and exchange of influence on behalf of youth leaders and civil society organizations during the 'Arab spring' uprisings is yet another reflection of Pan-Arabism's resilience. ${ }^{28}$ This strand of PanArabism, however, embodies a more bottom-up grassroot dimension anchored on demands for democratic reform, inclusivity and good governance. $^{29}$

If Pan-Arabism is a parochial cultural movement anchored on a shared language and ethnic identity, then Pan-Africanism's is a more ambitious ideology transcending ethnic, cultural, linguistic and religious affiliations. Pan-Africanism was first articulated as a movement that sought to restore pride, independence and dignity 'among all those of Negro stock', by establishing a greater sense of solidarity and oneness that can connect the displaced people of the diaspora with their descendants in Africa. ${ }^{30}$ However, it has since evolved to five dimensions each of which speak to contestations over whom is entitled to an African identity: Sub-Saharan; Trans-Saharan; Trans-Atlantic; West Hemispheric; and Global PanAfricanism. Others view these dimensions as part of an evolutionary sequence demonstrating the growth and inclusivity of the movement. ${ }^{31}$

Collin Legum derived nine key objectives from Pan-Africanism as it was articulated in the mid-20 th century: 'Africa for Africans' and independence of the whole of Africa; United States of Africa: through a series of interlinking regional federations; African renaissance of morale and culture; African regeneration of economic enterprise; African Nationalism to transcend regional and tribal affiliations; Belief in democracy; Rejection of violence as a method of struggle; Solidarity of black peoples everywhere; Positive neutrality: but 'neutral in nothing that affects African interests'. ${ }^{32}$

When viewed in light of these objectives, Pan-Africanism appears to be making notable institutional progress. The AU is now the most formally

\footnotetext{
${ }^{27}$ Arab Center for Research and Policy Studies (2012), Geostrategic balances and interactions and the Arab revolutions. Available at: http://www.dohainstitute.org/file/pdfViewer/12364757-aa51-4c5fbe8ad5d3df803708.pdf [Accessed 21 March 2019]

${ }^{28}$ Sawani, Youssef (2012), 'The End of Pan-Arabism' Revisited: Reflections on the Arab Spring', Contemporary Arab Affairs 5(3), pp. 382-397

${ }^{29}$ Temlali, Yassine (2012), 'The "'Arab Spring" Rebirth or Final Throes of Pan-Arabism? Perspectives', Contemporary Arab Affairs 5(3), pp. 382-397

${ }^{30}$ Colin, Legum (1962), Pan-Africanism: A Short Political Guide (Frederick A. Praeger Publishers), pp. 16-26

${ }^{31}$ Mazrui, Ali (1977), Africa's International Relations, The Diplomacy of Dependency and Change (Heinemann; Westview Press London)

32 Legum (1962), pp. 38-39
} 
acknowledged advocate of Pan-Africanism and is assuming increased leverage in international affairs. Its progressive and robust mandate for intervention in crimes against humanity; the deployment of AU troops in peacekeeping operations such as AMISOM; the increased number of democracies emerging across the continent; the ratification of Agenda 2063; and the growing role of regional economic communities (RECs) in fostering integration and managing conflict, all point to a slow but dynamic process of realizing longstanding Pan-African ideals. This process is indisputably ridden with challenges, the most conspicuous being the AU's inability to finance its own peace-keeping operations, to act in the face of wide-spread human rights abuses and to exercise authority over despotic leaders who pursue self-interest at the detriment of regional interest. Nonetheless, the organization has left its mark on the continent by making notable progress towards change, particularly when compared to its counterpart, the LES.

Attempts to merge Pan-Arabism and Pan-Africanism involved more compromise from the side of the latter. It was not until Egyptian president Gamal Abdel Nasser put forward a series of initiatives in the 1950's to increase Arab-African cooperation that Pan-Africanism was expanded to include North-Africans. ${ }^{33}$ This, however, was not achieved without opposition. Many leaders at the time insisted that unifying Black Africa should remain the priority and that Arab internal quarrels would add unnecessary frictions in the Pan-African movement, a claim that still bears truth to date ${ }^{34}$ Nonetheless, the fight against colonialism required wider alliances among 'peoples of other colours' who were also victims of white supremacy, hence DuBois's famous statement that 'the problem of the $20^{\text {th }}$ Century' is 'the problem of the colour line - the relation of the darker to the lighter races of men in Asia and Africa'. ${ }^{35}$

Pan-Africanism's expansion into a racially inclusive process anchored on elements of humanitarianism and democratic regionalism can account for why the AU has enjoyed relatively greater success in establishing a viable political project. At the core of the AU is a desire to produce an 'African personality to recast African society into its own forms, drawing from its own past what is valuable and desirable'. This indefinite approach allows space for the African identity to be continuously negotiated while simultaneously embarking on political reforms that complement and

\footnotetext{
33 Nantambu, Kwame (1998), 'Pan-Africanism Versus Pan-African Nationalism: An Afrocentric Analysis', Journal of Black Studies 28(5), pp. 561-574

${ }^{34}$ Bankie (2008)

${ }^{35}$ As cited by DuBois in Legum (1962), p. 25
} 
strengthen this process of identity formation. ${ }^{36}$ Pan-Arabism, on the other hand, remains a linear ideology that advances Arab thought and processes without much consensus of what constitutes an Arab in the modern world and a refusal to negotiate its political shortcomings. ${ }^{37}$ This reality makes it difficult to identify Africa's role in North-African affairs. For example, when an attempt was made by the OAU to intervene in the Algerian-Moroccan border conflict, Arabs rejected African intervention deeming the conflict 'an internal Arab affair'. ${ }^{38}$ This paper's subsequent case studies examine the extent of which power possessed by North-African states is translated into influence in Africa and attempts to extract conditions under which the PanAfrican and Pan-Arabism can be synchronized.

\section{Pan-Africanism and the Arab-Israeli Conflict (1967-1979)}

\section{The Limitations of Hegemony}

The Arab-Israeli conflict has been a source of unity and division in the trajectory of Arab-African relations. The OAU and the AU's recurrent condemnation of Israel's occupation of Palestine has been casted as an outcome of Arab-African solidarity by some and a reflection of Arab supremacy over African affairs by others. The founding fathers of PanAfricanism including Dubois, Padmore and Nyerere believed in the natural connection between Zionism and Pan-Africanism due to the historical parallels affecting Jews and Black Africans. The exile of Jews and the scattering of blacks, the presence of Jewish ghettos and black ghettos and the events of slavery and the holocaust generated sympathy among both parties. ${ }^{39}$

When the first Arab-Israeli wars broke out, first in 1948 and then 1956, much of Black Africa was still under colonial rule and too politically

\footnotetext{
${ }^{36}$ Legum (1962), p. 21

${ }^{37}$ See example Gumbo, Bekezela (2014), 'The Hobbesian Nightmare in the Arab League: A Collision of Identity Politics and National Interests in Middle East Conflicts', Journal of Political Science and Public Affairs 2(4); Barakat, Halim (1993), The Arab World: Society, Culture, and State (Berkeley: University of California Press)

${ }^{38}$ Hassouna, Hussien (1975), The League of Arab States and Regional Disputes (Oceana Publication: New York)

39 Brackman, Harold (2000), 'A Calamity Almost Beyond Comprehension": Nazi AntiSemitism and the Holocaust in the Thought of WEB Du Bois', American Jewish History 88(1), pp. 53-93. It cannot be undermined, however, that the British government offered Dr. Theodare Herzl, the founding father of Zionism, a Jewish state in parts of Uganda and Kenya, to which he refused saying 'Our starting point must be in or near Palestine. Later on we could also colonize Uganda'. The 'Arab-Israeli' issue could have easily been an 'AfricanIsraeli issue' had this offer been accepted. See: Mazru, Ali (1979), 'Africa and the ArabIsraeli conflict' in Historical and Socio-cultural Relations Between Black Africa and the Arab World from 1935 to the Present (Published by UNESCO)
} 
neutralized to have a substantial reaction to the conflict. Yet following independence, SSA states enjoyed friendly relationships with Israel, much the dismay of Arabs. Israel granted loans to many African states and Israeli private companies in contraction with African governments embarked on vast development projects in various sectors. ${ }^{40}$ This was reciprocated with political solidarity for the Zionist cause. During the First Conference of Independent African states held in Accra in 1958, Black Africa succeeded in preventing the Arab majority from labelling Israel as a 'racist' and 'imperialist' power. ${ }^{41}$

Nowhere was Pan-African's neutrality to Zionism more evident than in Nkrumah's close relationship with Israel. After independence, Accra became the most influential Israeli foreign mission. Nkrumah introduced Israel to his Pan-African nationalist counterparts including Tom Mboya and Julius Nyerere, who welcomed Israeli diplomatic missions in their home countries. ${ }^{42}$ In his first address to the UN in 1960, Nkrumah, called upon Arab leaders to recognize the 'realities' of Israel's existence. In turn, Nasser made Nkrumah the target of Cairo Radio propaganda to which Nkrumah responded that one should be cautious of 'direct Egyptian expansionism or indirect communist penetration of African areas through a willing Egypt'. 43

As negotiations over the construction of the OAU flourished, more Black African leaders began denouncing Israel. Nonetheless, the period from 1963 onwards depicted a discernible discrepancy between the verbal condemnations of Israel's occupation of Palestine and the close bilateral relations Black African states maintained with Israel. Black African states were sceptical of Arab hegemony and feared that the Arab-Israeli conflict would take precedence over other exigent African affairs. The Monrovian group - who exerted greater influence in the OAU - was reluctant to take a strong stance against Israel partially due to fears that Egypt would use the $\mathrm{OAU}$ as a vehicle to counter Israel. ${ }^{44}$ When foreign ministers from respective

\footnotetext{
${ }^{40}$ Loans were granted to including Ghana, Ivory Coast, Nigeria, Liberia Sierra Leone and Tanzania Jacob, Abel (1971), 'Israel's Military Aid to Africa, 1960-66', The Journal of Modern African Studies 9(2), pp.165-187

${ }^{41}$ Nadelmann, Ethan (1981), 'Israel and Black Africa: A Rapprochement?', The Journal of Modern African Studies 19(2), pp. 183-219

42 Levey, Zach (2003), 'The Rise and Decline of a Special Relationship: Israel and Ghana 1957-1966', African Studies Review 46(1), pp. 155-177

${ }^{43}$ As cited in Adeoye (1980), p. 91

44 The Monrovia group was alliance of states in the OAU who believed that independent states should co-operate and exist in harmony, but without a supranational political federation that was endorsed by their main rival, the Casablanca Group. Key states in the Monrovia group included Liberia, Nigeria and most of Francophone Africa, including Senegal and Cameroon
} 
African countries met to prepare for the OAU's construction, Egypt was propelled to provide a verbal assurance that its commitments to the Middle East and Africa would not contradict one another. ${ }^{45}$ Despite this reassurance, North-African states continued to raise the issue of Israel in every African convening, further alienating many Black African states. ${ }^{46}$

Conscious of the tensions caused by the injection of the Arab-Israeli conflict into African affairs, North-African leaders attempted to downplay their exertions. In the 1963 Addis Ababa Conference and the 1964 Cairo Summit, Arab leaders decided not to push for a resolution on the Middle East. This, however, did not stop them from referencing the conflict in speeches and drawing comparisons between Israel and South Africa. ${ }^{47}$ In the 1964 Cairo summit, President Ben Bella proposed that African states consider a boycott of Israel because:

'If we are talking about boycotting South Africa, all of us know that 75 percent of Israel's trade is with Africa, and that Israel appears in every place vacated by colonialism to offer capital from Israel and from European banks'. 48

Not only was his proposal rejected, but Black-African leaders responded by affirming that 'all countries today either co-exist or are interdependent, relying on each other's generosity, assistance, or cooperation' ${ }^{49}$

Even after the humiliating defeat of Arabs including Egypt, an OAU member state, in the 1967 six-day war, African states were still reluctant to pass a resolution condemning Israel. Following the war, Somalia called for an emergency OAU summit to issue a stance. Most member states rejected the call arguing that the UN was the best authority to address the conflict..$^{50} \mathrm{~A}$ few months later, respective leaders chose only to adopt a 'declaration' as opposed to a resolution which carefully refrained from referring to Israel as an 'aggressor'. The declaration merely expressed concern by the 'grave situation' and offered its 'sympathy' for the United Arab Republic (UAR); a short-lived sovereign state and political union between Egypt (including the occupied Gaza Strip) and Syria from 1958-1971. Beyond the

\footnotetext{
${ }^{45}$ Woronoff, Jon (1970), Organizing African Unity. Metuchen (Scarecrow Press, New Jersey)

${ }^{46}$ Miller, Jake (1975), 'African-Israeli relations: Impact on continental unity', Middle East Journal 29(4), pp. 393-408

47 El-Khawas, Mohamed (1975), 'Africa and the Middle Eastern Crisis', African Issues 5(1), pp. 33-42.

48 Ibid p. 36

${ }^{49}$ Mboya, Tom (1963), Freedom and After (Andre Deutsch; London), p. 23

${ }^{50}$ Africa Research Bulletin (1967), 4(7), p. 815
} 
acknowledgment that the UAR was 'an African country whose territory is partially occupied by a foreign power', the declaration had little-if anyimpact. ${ }^{51}$

Failing to convert their referent and/or persuasive power into influence, North-African leaders resorted to coercive and/or reward power. Qaddafi's emergence in September 1969 meant that 'Petro-Dollars' could be injected into Africa in exchange for political support. Gaddafi led an extensive antiIsrael propaganda campaign that promised generous financial assistance to states that sever ties with Israel.52 Following his visit to Libya in 1972, Ugandan president Idi Amin broke relations with Israel in exchange for financial assistance from Gaddafi. Amin then flew to Chad to convince his fiscally constrained counterpart President Tombalbaye of the benefits of reaching an agreement with Tripoli. Gaddafi also did not hesitate to deploy force when needed. For example, he only agreed to halt his overt funding of Northern Toubou rebel groups in Chad after Chad conceded to breaking ties with Israel.53

These coercive measures, albeit marginally successful in inducing some SSA states to break ties with Israel, failed to garner the level of support NorthAfricans had anticipated. It also generated resentment from OAU members who became more apprehensive of attempted Arab dominance. ${ }^{54}$ At the same time, North-Africa's hegemonic pursuits were increasingly condoned at a grassroots level. In a Nigerian Newspaper editorial, captioned 'Arab First, Arab Last', the author argued that Arabs continuously prioritize their interests before those of Africa, referring specifically to how Egypt exploits Pan-African and Afro-Asian conferences to brand Israel an 'imperialist base' in Africa. ${ }^{55}$ Hegemonic tacticts not only failed to shift opinion in favour of an anti-Israel stance, but also became a major point of contestation that threatened the very foundations of a Pan-African project itself. At this stage, it was evident that a different approach was needed to foster sincere support for the Arab-Israeli conflict.

\section{Transiting from Hegemony to Leadership}

By 1973, a remarkable wave of anti-Israeli sentiment began to infiltrate the African continent. In less than a year, 27 SSA states broke ties with Israel

\footnotetext{
${ }^{51}$ Africa Research Bulletin (1967), 4(9), p. 856

52 Peters, Joel (1992), Israel and Africa: The Problematic Friendship (IB Tauris)

53 Burt, Sally and Anorve, Daniel (2016), Global Perspectives on US Democratization

Efforts: From the Outside In (Palgrave Macmillan)

54 Peters (1992), p. 34

55 Akinsanya (1980), p.94
} 
leaving the continent almost unanimously united in a common position. In October 1973, Congo's president Seko surprised the world while addressing the UN by stating that he was forced to choose between 'Israel a friend and Egypt a brother'. ${ }^{56}$ Ethiopia, a longstanding critic of Arab meddling in the internal affairs of African countries and a strong ally of Israel, switched positions after much contemplation. ${ }^{57}$ Similarly, when explaining his newly adopted position the president of Zaire declared:

'We have taken this decision at a great risk, because many of our officers-and I myself-have received military training at the hands of Israeli officers who came to our country at our expense. By declaring this decision to the world from the largest Jewish city in the world [New York City], I mean to stress the fact that Zaire will never back down and will carry out the duties of African co-operation.'58

The severance of diplomatic relations was complimented by a series of OAU resolutions endorsing the most adverse positions towards Israel to-date. The May 1973 OAU resolution warned that occupation of Arab territory constituted an act of aggression that threatens the security of the African continent and demanded OAU member states - either individually or collectively - to take political and economic measures against Israel. In addition, nineteen SSA states voted for UNSC resolution 3379 in 1975 that equated Zionism with racism while the majority of OAU states demonstrated profound consistency in voting against Israel on every UN resolution pertaining to the Arab-Israeli dispute from 1973 onward. ${ }^{59}$

Among the reasons presented by scholars for this abrupt shift in attitudes towards Israel was the 1973 oil embargo that left many African states dependent on Arabs to compensate for price hikes, the increase in hefty aid packages granted by oil-producing states, Israel's poor choice of diplomatic personnel who were insensitive to issues in host countries and the competitive advantage gained by Arab states in the 1973 Yom Kippur War. While these factors may have played a role, they fail to consider the chorological order in which these events occurred. Signs of a major change in African sympathies manifested before OPEC's decision to quadruple oil prices and Arab states' advance in the 1973 war. The May 1973 OAU resolution indicates that opinions in Africa were shifting in favour of Arabs before OPEC's muscle-flexing and the Yom Kippur War.

\footnotetext{
56 Mazrui (1979)

${ }^{57}$ Ibid

${ }^{58}$ As citied in Mazrui (1975), p. 736

${ }^{59}$ Levey, Zack (2008), 'Israel's Exit from Africa, 1973: The Road to Diplomatic Isolation',

British Journal of Middle Eastern Studies 35(2), pp. 205-226
} 
The missing factor overlooked by scholars is the leadership processes that occurred during this period. Prior to 1973, hegemonic action was the norm but post-1973 North-African states completely transformed the ways they engaged with their SSA counterparts, by embarking on leadership processes that effectively generated genuine support for their cause and promoted a continental strand of unity. The push away from hegemony and pull towards leadership not only accounts for the sincerity, speed and spontaneity in which a pro-Arab stance crystalized but also explains why these stances came from countries who were not initially recipients of Arab aid packages.

Take, for example, the May 1973 OAU meeting noted above. During the meeting, Algerian president Boumediene carefully articulated the Arab position in a way that merged Arab struggles with African ones by drawing parallels between apartheid, colonialism and Zionism. He compared Israeli's occupation of Arab lands to the appropriation of African lands by foreign races in South Africa. He stressed that 'Africa cannot adopt one attitude towards colonialism in Southern Africa and a completely different one towards Zionist colonization in Northern Africa.' He further suggested that Israel's occupation of the Sinai Peninsula all the way to the Suez Canal, nearly a third of Egyptian land following the 6-day war, was an insult to the African continent. These parallels although previously suggested were not articulated with such relatability and sophistication. ${ }^{60}$ The reframing of the conflict from an 'Arab' one to an 'African' one engaged African states as direct actors in the conflict as opposed to mere bystanders exploited into choosing sides.

North-African leaders supplemented a change in rhetoric with actions that reaffirmed their commitment to pertinent Pan-African issues. Following the May 1973 OAU resolution, they began to address more rigorously the issue of apartheid South Africa, managing to convince their Asian-Arab companions to adopt stern measures against the apartheid state. The 1973 Conference of Arab Kings and Presidents in Algiers successfully responded to the OAU's request of utilizing oil as a political weapon against apartheid Southern Africa and even went further in proposing an Arab-African summit to widen the scope of solidarity. A resolution was passed declaring all Arab states that have not already done so to sever diplomatic, consular, economic and cultural ties with South Africa, Portugal and Rhodesia and approving a strict oil embargo on the three countries. The same resolution

60 Polakow-Suransky, Sasha (2010), The unspoken alliance: Israel's secret relationship with Apartheid South Africa (Jacana Media) 
rendered political and material assistance to African liberation movements fighting those three respective states. ${ }^{61}$

Another example of the mutuality produced during this process was the ways in which North-African leaders responded to the concerns of increased oil prices on African economies. At the January 1974 Afro-Arab cooperation conference, African states demanded privileged prices of their oil supplies. Their request was rejected on two legitimate grounds: Firstly, a double price policy was subject to abuse by the multinational oil companies which still controlled the distribution process in Africa; Secondly, Oil prices are fixed by OPEC and could not be unilaterally altered by its members. However, as a gesture of goodwill, Arab countries promised the OAU \$200 million to offset the losses of African countries most severely affected by the surge in oil prices. ${ }^{62}$

Prior to 1973, Israel - the enemy of the Arabs - was not inherently the adversary of the Africans, and South Africa - the enemy of the Africans - was not inherently the adversary of the Arabs. ${ }^{63}$ North-African leaders' decision to endorse the fight against apartheid South Africa almost to the same degree as the fight against Israel coincides with the perspective that leadership processes requires an exchange of influence between both leaders and followers in which both actors are affected. Whereas hegemony is one sided, relying heavily on coercive and reward power to achieve results, leadership processes rely on consensus building and a fusion of interests to unite leaders and followers under a common goal. It was the transmission of values as opposed to the transmission of inducements that produced solidarity.

However, hegemonic attempts were not entirely absent. Take, for example, Gaddafi's actions prior to the $10^{\text {th }}$ OAU Anniversary Summit held in May 1963 where he sent cables to all African leaders demanding they boycott the meeting unless Ethiopia cut ties with Israel prior to the celebration or the venue would be changed to Cairo. His request was denounced by NorthAfrican leaders and the situation was saved by Boumediene who presented the dilemma with a tone of mutuality that won the support of African leaders.

\section{Libyan Civil War: Pan-Africanism and Pan-Arabism Revisited}

\footnotetext{
61 Mazrui (1975)

62 Červenka, Zdenek (1974), 'The Emergence and Significance of the African-Arab

Solidarity', Instant Research on Peace and Violence 4(2), pp. 102-109

${ }^{63}$ Agyeman, Opoku (1984), 'Pan-Africanism Versus Pan-Arabism: A Dual Asymmetrical

Model of Political Relations', Middle East Review 16(4), pp. 5-30
} 


\section{Domestic leadership processes: the missing piece of the puzzle}

Prior to the 2011 uprising in Libya, two assumptions prevailed. First, PanArabism failed to provide a relevant account for any major political occurrences post-1979 because it was, for all extent and purposes, dead among Arab leaders. Second, only pro-African leaders such as Gaddafi and Nasser can bridge the gap between African states North and South of the Sahara. The common denominator among these assumptions is the tendency to draw conclusions based on a linear understanding of leadership as those occupying positions of power in isolation from domestic processes of which they are subject.

From an outsider's perspective, Gaddafi's regime demonstrated a remarkable level of resilience and stability up until the 2011 uprisings. Bypassing years of internationally imposed sanctions, the Libyan Jumeriah achieved the highest standard of living in Africa, made remarkable progress in healthcare and education and attainted a degree of social and occupational empowerment of women yet to manifest in most Arab countries. ${ }^{64}$ In addition, Gaddafi was hailed as a true Pan-African who, unlike other North-Africans, invested in the development of the continent. His self-proclamation as 'the King of Africa', was bolstered by his financial and ideological contributions to the OAU/AU and his efforts to establish a 'United States of Africa'. 65 Thus, his downfall was a disappointment to many African leaders and a source of celebration to others including his Arab counterparts.

The indictments behind Gaddafi's downfall cannot be answered without reference to the historical processes that shaped the nation-building processes of the Libyan state. Just as the Free Officers' 1952 coup was evoked by frustrations with the incompetency of Egypt's armed forces in 1948 and the 1958 Iraqi revolution was a movement against the pro-British monarchy following the events of the Suez, the Al-Fateh revolution was a reaction to the 1967 Arab defeat and more critically Libya's absence from Arab affairs. Determined not to remain in the shadow of Arab events again, Gaddafi embarked on a strategic partnership with Nasser who helped resolve many problems faced by the new regimes, including suppressing

\footnotetext{
${ }^{64}$ Roberts, Hugh (2011), 'Who said Gaddafi had to go?', London Review of Books 33(22), pp. 8-18 65 Obala, Luke (2011), 'Africa and the Arab World after Gaddafi', Al Jazeera Centre for Studies Report
} 
the enduring nationalist rebellion in Cyrenaica (from 1969 onwards), where the 2011 uprising would first breakout. ${ }^{66}$

Following Nasser's death in 1970, Gaddafi attempted to establish a political union with Egyptian President Anwar Sadat. Anxious to assure that Sudan maintained a Pan-Arab orientation, Sadat and Gaddafi helped Sudanese President Nimeiri regain power after he was ousted in a coup and signed the Federation of Arab States. ${ }^{67}$ However, as Egypt began veering away from Pan-Arabism in favour a more unilateral policy agenda, tensions escalated, leading to the closure of the Libyan embassy in Cairo in 1973. Shortly after, Gadhafi attempted yet another alliance with Tunisia's Bourguiba, declaring a new 'Arab Islamic Republic' in 1974. When the alliance failed due to opposition from Algeria and Morocco, he proceeded to secure an alliance with Algerian president Boumediene. In 1975, Libya and Algeria signed a treaty of mutual friendship but Boumediene died shortly after. His successor, Bendjedid, emulated Sadat's unilateral nationalism and abandoned Algeria's Pan-Arab commitments. In his last attempt to establish an Arab Union, Gaddafi desperately signed a short-lived treaty with King Hassan of Morocco in 1984.68

Failing to secure a leadership position in North-Africa, Gaddafi turned to SSA where it was easier to situate himself as the benevolent patron. He quickly launched a domestic campaign to steer popular sentiment into the direction of Pan-Africanism. The same tools used to promote Arab propaganda were reconfigured to accommodate African propaganda. The name of the Libyan external radio service used to communicate his views was changed from 'the Greater Arab Homeland' to 'the Voice of Africa'. 69 School curriculums, media broadcasts and meeting agendas with different strata of society were reconfigured to accompany his new policy directions. Gaddafi announced that Libya was to become a 'black country' and encouraged Libyans to emigrate to different parts of Africa and marry Black Africans. However, the lack of influence exchanged by Gaddafi and his population in the process of shifting the nation's identity left his attempts vulnerable to failure. In a nationwide survey published in 2001 that explored notions of identity among university students, youth ranked Arabism and Islam as the most important layers of their identity, failing to

\footnotetext{
${ }^{66}$ Roberts (2011)

${ }^{67}$ Aguda, Oluwadare (1973), 'Arabism and Pan-Arabism in Sudanese Politics', The Journal of Modern African Studies 11(2), pp. 177-200

${ }^{68}$ Huliaras, Asteris (2001), 'Qadhafi's comeback: Libya and sub-Saharan Africa in the 1990s', African Affairs 100(398), pp. 5-25

69 Vandewalle, Dirk (2012), A History of Modern Libya (Cambridge University Press)
} 
distinguish between both identities ${ }^{70}$. This came as no surprise considering Gaddafi's propensity to conflate Arabism with Islam despite criticism that this approach excluded non-Sunni Muslims and Christians from the movement. ${ }^{71}$

Gaddafi's confidence in his ability to reverse decades of Pan-Arab enculturation through an impulsive top-down resocialisation process was misplaced. By equating external influence with internal influence and assuming that the former naturally generates the latter, he eventually lost both. Reorienting identity involves a long-term nation-building process anchored on effective leadership processes and shared visions. Gadhafi's public condemning of Arab states whom he accused of being docile agents of Western interests, reflected the bitter recognition that the Pan-Arab fervour behind the 1969 revolution was now obsolete. However, the African alternative he diligently pursued was not entirely endorsed by citizens who desired Libya to approximate to the more affluent and liberal Dubai, which in turn later spurred virulent resentment towards black Africans and the regime alike. As rightfully predicted by Robert Hugh:

'In taking Libya into Africa while tending to remove it from Arab regional affairs, the Jamahiriyya's foreign policy, like that of Idris's monarchy, cut the Libyans off from other Arabs, especially the wellheeled Gulf Arabs whose lifestyle many middle-class Libyans aspired to. In this way, the regime's foreign policy made it vulnerable to a revolt inspired by events elsewhere in the Arab world.'72

Thus, when the 2011 uprisings surfaced Libya was not immune from the turmoil. The relative absence of civil society, the dysfunctional character of the government's few formal institutions, the deliberate weakening of the armed forces (in fear of a coup) and the indispensability of Gaddafi himself as guardian of the state, were all factors that left Libya vulnerable to violent revolts. The emphasis on an Arab awakening, dignity and good governance espoused during the Arab Spring appealed to Libyans but the population's inchoate experience in political mobilization left it susceptible to more detrimental outcomes. The fact that neither Mubarak nor Ben Ali were founding fathers of their respective states allowed protesters in Egypt and Tunisia to distinguish between a rebellion against the regime and a rebellion against the state. The presence of an armed forces loyal to the nation was crucial in preventing state collapse. In Libya, however, the revolt

${ }^{70}$ Centre for Arab Unity Studies (2012), 'Arab public opinion towards Arab unity'. Centre for Arab Unity Studies, Beirut Unpublished report

71 Obeidi, Amal (2011), Political Culture in Libya (Psychology Press)

72 Roberts (2011) 
threatened Gaddafi's regime and the Jamahiriya as a whole. ${ }^{73}$ The longdelayed national conversations as to whether Libyans desired the same Pan-African ideals hegemonically pursued by Gaddafi were now to be violently confronted.

Libya's 2011 uprising demonstrates the shortcomings of regional hegemonic pursuits in the absence of effective leadership processes domestically. Identity formation is one of the most significant aspects in the construction of a nation and political community and necessitates an inclusive leadership process. It is a sensitive, complex and continuous set of negotiations that demands aligning of interests, the exchange of mutuality and persuasion or, in other words, the ability to convert power to influence. The unilateral, authoritative and hastened nature through which Gaddafi attempted to replace Arab nationalism with African nationalism not only jeopardized his regional ambitions but ultimately contributed to the collapse of his regime. Despite all the socioeconomic accomplishments to which his regime can accredited for, Gaddafi failed to view leadership as a socialization process that creates shared values and goals among followers. As noted earlier, a hegemon that fails to make major concessions to its domestic population risks demise.

\section{The Convergence of Domestic and Regional Hegemony: Implications and Consequences}

The 2011 civil war in Libya presented a golden opportunity for the League of Arab States and the AU to reinforce their Pan-Arab and Pan-African ideals of combatting foreign intervention by collectively resolving the situation before the international community took a lead. Instead, both organizations indirectly competed for agency by endorsing opposing views. Despite the AU's closer relationship with Gaddafi, it was the LAS that emerged as the regional representative on the crisis. In March 2011, Resolution 1973 was adopted by the United Nations Security Council (UNSC) forming the legal basis for military intervention. The resolution demanded an immediate ceasefire, established a no-fly zone over Libya and endorsed the use of all means short of foreign occupation to protect civilians. It explicitly reaffirmed the LAS's primacy in regional affairs by emphasizing the 'important role of the Arab League in matters relating to the maintenance of international peace and security in the region' and requested LAS member states to work with the UN to implement the resolution. On the contrary, the council merely 'took note' of the African Union's Peace and

73 Ibid 
Security Council's efforts. ${ }^{74}$ The AU was largely against resolution 1973, denouncing all types of foreign intervention threatening Libya's territorial integrity. In a BBC programme, the chairperson of the AU commission, Jean Ping, affirmed the side-lining of the AU in the Libyan crisis by accusing the international community of deliberately avoiding consultations with the AU.75

One must consider earlier situations that enabled the LAS to assume primacy over the situation. Shortly after UNSC Resolution 1973 was adopted, the LAS, the AU, the EU and the UN held a meeting at the LAS headquarters 'to discuss the situation in Libya and further coordinate their efforts'. The Quartet resulted in a report that 'recognized the important role' of the AU, the UN and the EU but asserted the 'responsibility of the League of Arab States to promote a peaceful resolution of the situation in Libya' ${ }^{76}$

The responsibility assumed by Arab states was driven by contrasting hegemonic motives. The transitional governments in Egypt and Tunisia, under pressure from civil society and vehement protesters, endorsed the resolution to highlight their support of the uprisings. ${ }^{77}$ Morocco was motivated by strategic ambitions of securing a new ally in the Western Sahara dispute. Only a day after the rebel forces seized control of Tripoli, Morocco recognized the National Transitional Council (NTC) as a legitimate representative of the Libyan people. In return, the NTC promised to endorse Morocco's stance on the Western Sahara dispute and terminate cooperation with the Polisario Front. ${ }^{78}$ Similarly, Sudan sought the opportunity to topple a long-standing menace who covertly funded almost everything causing

\footnotetext{
${ }^{74}$ UNSC (2011), United Nations Security Council Resolution 1973 (2011) on Libya. Available at https://www.nato.int/nato_static/assets/pdf/pdf_2011_03/20110927_110311-UNSCR1973.pdf (Accessed 29 March 2019)

75 BBC Hard Talk (2011), 'AU “Ignored” over Libya Crisis', Available at: http://news.bbc.co.uk/2/hi/programmes/hardtalk/9436093.stm (Accessed 28 March 2019)

${ }^{76}$ European External Action Service (2017), Meeting of the Libya Quartet: Joint Communiqué. Available at: https://eeas.europa.eu/headquarters/headquartershomepage en/26764/Meeting\%20 of\%20the\%20Libya\%20Quartet:\%20Joint\%20Comm uniqu\%C3\%A9 (Accessed 28 March 2019)

77 In a coordinated effort from over 200 Arab organizations and prominent intellectuals from across 18 Arab countries, an open letter in favour of international intervention was sent to world leaders, demonstrating civil society's overwhelming support for resolution 1973. See: Rogin, Josh (2017), 'Over 200 Arab groups call for Libya no-fly zone', Foreign Policy. Available at: https://foreignpolicy.com/2011/02/25/over-200-arab-groups-callfor-libya-no-fly-zone/ (Accessed 28 March 2019)

78 Morroco World News (2011), Morocco confirms recognition of Libyan Transitional Council. Available At: https://www.moroccoworldnews.com/2011/08/7536/moroccoconfirms-recognition-of-libyan-transitional-council/7536/ (Accessed 28 March 2019)
} 
instability in the Sudan, including activists in Darfur. ${ }^{79}$ Algeria, Syria and Yemen were the only Arab states who voted against military intervention fearing that Gaddafi's fall would set a precedent for their own regimes. Although Algeria was relatively consistent in its opposition to foreign invention, it did little to coordinate efforts between the LAS and the AU.

Many factors compelled the AU to concede authority to the LAS prior to the adoption of Resolution 1973. Firstly, the uprisings were perceived by the international community and the protesters themselves as being part of an 'Arab Spring', not an African one, making it difficult for the AU to assume leverage. Secondly, the NTC first approached the LAS and cooperated closely with it to find a solution, perhaps to establish ties with the Arab nation that Gaddafi had isolated them from. The NTC also interrogated the AU's credibility, dismissing it as Gaddafi's sphere of influence and refusing to consider any of the AU's proposed roadmaps. ${ }^{80}$ In fact, the AU was greeted by hostile demonstrators when it arrived in Benghazi. ${ }^{81}$ Thirdly, the AU's response was relatively slow and incoherent due to its reluctance to support the fall of its biggest sponsor while Arab leaders quickly seized the opportunity to avenge their long-standing nemesis. Fourthly, even if the AU was granted an opportunity to intervene, their mandate stipulates that this intervention should be carried out by African Standby Forces derived from Regional Economic Communities (RECs). Due to hostilities among Arab leaders, North Africa is yet to construct a viable REC encompassing all North African states, adding an additional barrier to AU intervention in any NorthAfrican affairs. ${ }^{82}$ Lastly, one cannot negate the impact of western forces,

\footnotetext{
${ }^{79}$ Elhag, Assim (2012), 'The Sudanese Role in Libya 2011', World Peace Foundation. Available at: https://sites.tufts.edu/reinventingpeace/2012/12/17/the-sudanese-rolein-libya-2011/ (Accessed 28 March 2019)

${ }^{80}$ Kasaija, Phillip Apuuli (2013), 'The African Union (AU), the Libya Crisis and the notion of 'African solutions to African problems', Journal of Contemporary African Studies, 31(1), pp. 117-138,

${ }^{81}$ Tran, Mark (2011), 'Libyan Rebels Protest over African Union Peace Mission', The Guardian. Available at: https://www.theguardian.com/world/2011/apr/11/libya-rebelsprotest-peace-mission (Accessed 28 March 2019)

${ }_{82}$ Although the Arab Maghreb Union is officially recognized as the REC of North Africa, it fails to some of the key actors in the region such as Egypt and Sudan and has remained inactive since 1994. North African states have since attempted to construct the North African Regional Capacity (NARC) to fill the sub-regional vacuum and act as the implementing wing of the African Standby Force but plans were obstructed due to the events of the Arab Spring. Damidaz, Nima and Sorenson, Karl (2009), 'To have and havenot: A Study on the North African Regional Capacity', published by FOI, Swedish Defence Research Agency. Available at: http://www.asclibrary.nl/docs/370/138/370138384.pdf (Accessed 28 Mach 2019)
} 
specifically Britain and France, who worked diligently to mobilize support for resolution 1973.83

The Libyan civil war also revealed a relatively new challenge: an anti-PanAfrican population. Following Gaddafi's downfall, Libya quickly transformed from being the regional hub for African economic migrants to the central arena for a fully-fleshed slave trade. One International Organization for Migration officer described the situation as 'Arabs - buying sub-Saharan migrants' while another senior officer for Human Rights Watch attested 'I've seen very widespread racism and xenophobia in Libya...Dark skinned people in general face discrimination. If you're a Syrian Arab who speaks the language, you're definitely better off.' 84 The TNC's repeated accusations that Black Africans residing in Libya were hired as mercenaries by Gaddafi has fuelled racial violence that claimed the lives of many. For the first time, the AU was not just challenged by hegemonic North-African leaders who rejected its influence, but equally by hostile populations not in favour of 'African Solutions to African problems'. The widespread atrocities committed by Libyans against Black-Africans since the civil war is a one of the repercussions of Gaddafi's ill calculated attempts to pursue regional hegemony in Africa without domestic support.

\section{Conclusion}

Pan-Arabism and Pan-Africanism paradigms have evolved over the years with emergent challenges that leaders must now consider. Pan-Arabism once a top-down cultural policy imposed through a close alliance among Arab ruling elites - is now shifting into a grassroot movement anchored on demands for good governance, dignity and social justice directed against incumbent regimes. The issues that bonded political elites in the past are now minimal, if existent at all, yet the memory of their ideals remains a selfinflicted predicament. It is no coincidence that the most radical Pan-Arab regimes at one point in time, namely Libya, Syria, Egypt and Tunisia, were the states most affected by the 'Arab-Spring'. In contrast, Pan-Africanism has shifted from being a black consciousness movement to a more institutionalized set of political ideals encompassing all 'African peoples of colour'. Both movements are now threatened by reliance on the West, lack of inclusive decision-making processes at home, the rise of Pan-Islamism as

\footnotetext{
${ }^{83}$ See for example Grovogui, Siba (2011), 'Looking Beyond Spring for the Season: An African Perspective on the World Order after the Arab Revolt', Globalizations 8(5), pp. 567-572

${ }^{84}$ Sengupta, Kim (2011), 'Rebels settle scores in Libyan capital', The Independent. Available at: http://www.independent.co.uk/news/world/africa/rebels-settle-scores-inlibyan-capital-2344671.html (Accessed 29 March 2019)
} 
a competitive alternative and the national interests that reign supreme over regional prosperity.

The first case study presented, the Arab-Israeli conflict within the context of the OAU, demonstrates the constructiveness of leadership processes in merging Pan-Arab and Pan-African interests. The transition from hegemony to leadership and emphasis on mutuality and reciprocity helped procure genuine African support for the Arab position and in turn induced Arab leaders to become more invested in Pan-African issues such as Apartheid South Africa. These interactions were bolstered by the domestic support that North-African leaders enjoyed in framing Israel as an 'Arab national security' concern. Such grassroot endorsement of Pan-African issues in North-Africa was lacking, allowing Arab leaders to exert regional influence without needing much support from their population. Leadership processes during this period were effective because the Arabs themselves were arguably the most united they have ever been, making it possible to collectively utilize the OAU as an engine for change and in turn contribute to the OAU in a way that serves Pan-African agendas.

The 2011 Libyan civil war and subsequent military intervention demonstrate that reconciling Pan-Arabism and Pan-Africanism in today's context is a question of inclusion. Arab regional pursuits are now largely driven by unsuccessful hegemonic attempts to deflect attention away from the deficit of domestic leadership process and the crisis of legitimacy. Merging Pan-Arabism and Pan-Africanism is not just a matter of overcoming hegemony regionally: it must also promote effective leadership processes domestically. Gadhafi's hegemonic pursuits through the exploitation of Pan-Africanism were hampered by lack of popular support in his unilateral decision to shift the nation's orientation from being PanArab to Pan-African. This reality was exploited by Arab leaders who, motivated by desires to preserve their status and mask domestic failures, marginalized the AU from mediation efforts to ensure Gaddafi's downfall. Hegemonic pursuits in North Africa are now multifaceted, whereby Arab leaders seek hegemony over domestic populations, over African affairs and over each other. In the absence of sub-regional and regional leadership approaches, the prospect for constructive relations among North African states as well as among North Africa and SSA remains bleak.

The reality is that Pan-Africanism cannot be promoted in North-Africa without nationwide dialogues reassessing the state of Pan-Arabism and deliberating how Pan-Africanism can be accommodated within this context. Tunisia reaffirmed its 'Arab-Muslim identity' in its newly passed 2014 
constitution, the first North-African constitution derived through an inclusive and democratic process. Failing to make any specific mention to Africa, the constitution explicitly affirmed that Tunisia is 'part of the Arab Maghreb and works towards achieving its unity and takes all measures to ensure its realization'.85 The situation in Libya as of 2011 also affirms that a Pan-African orientation is unlikely to be endorsed by the TNC, the first democratically elected government. Sudan is still recovering from one of the bloodiest conflicts on the continent due to exclusive processes that sought to secure Arab hegemony. Morocco's recent rapprochement with the African Union in 2017 is a positive step but it remains unclear to what extent it was motivated by strategic interests and the disconcerting state of Arab politics. Military regimes in Egypt and Algeria continue to suppress domestic voices making it unclear what vision leaders and followers share regarding their role on the continent. By being granted the opportunity to influence the Pan-African movement without being fully invested in it, hegemonic interactions are likely to continue governing Arab leaders' interactions in Africa.

*African Leadership Centre, King's College London

\section{BIBLIOGRAPHY}

Arab Center for Research and Policy Studies (2012), 'Geostrategic balances and Interactions and the Arab Revolutions'. Available at:

http://www.dohainstitute.org/file/pdfViewer/12364757-aa51-4c5fbe8ad5d3df803708.pdf (Accessed 21 March 2019)

African Union (2000), Constitutive Act of the African Union. Available at: https://au.int/sites/default/files/pages/32020-file-constitutiveact en.pdf (Accessed: 28 March 2019)

Africa Research Bulletin, vol. 4, no. 7, 15 August 1967, p. 815

Africa Research Bulletin, vol. 4, no. 9, 15 October 1967, p. 856

African Union (2015), Report of The Chairperson of The Commission on The Situation In Libya, African Union, Addis Ababa Peace and Security Council 500th MEETING

\footnotetext{
${ }^{85}$ Constitution of The Tunisian Republic (2014) Articles 5\&39 Translated and printed by: Jasmine Foundation - Tunisia. Available at: www.jasminefoundation.org (Accessed 28 March 2019)
} 
African Union (2016), Communiqué of The Meeting of The AU High Level Committee On Libya Addis Ababa

Aguda, Oluwadare (1973), 'Arabism and Pan-Arabism in Sudanese Politics', The Journal of Modern African Studies 11(2), pp. 177-200

Agyeman, Opoku (1984), 'Pan-Africanism Versus Pan-Arabism: A Dual Asymmetrical Model of Political Relations', Middle East Review 16(4) pp 530

Akinsanya, Adeoye (1980), 'The Afro-Arab Alliance: A Dream or Reality?', Journal of the Historical Society of Nigeria 10(2), pp. 87-104

Andrew, Fenton; Higgott, Richard and Nossal, Kim Richard (1991), 'Bound to follow? Leadership and Followership in the Gulf Conflict', Political Science Quarterly 106(3), pp. 27-49

Barakat, Halim (1993), The Arab World: Society, Culture, and State (University of California Press)

Bankie, Bankie Forster and Mchombu, Kingo (2008), PanAfricanism/African nationalism: strengthening the unity of Africa and its diaspora (Red Sea Press)

BBC Hard Talk (2011), 'AU “Ignored” over Libya Crisis'. Available at: http://news.bbc.co.uk/2/hi/programmes/hardtalk/9436093.stm (Accessed 28 March 2019)

Brackman, Harold (2000), 'A Calamity Almost Beyond Comprehension": Nazi Anti-Semitism and the Holocaust in the Thought of WEB Du Bois', American Jewish History 88(1), pp. 53-93

Burns, James (1978), Leadership (Harper \& Row, New York), pp. 380-383

Burt, Sally and Anorve, Daniel (2016), Global Perspectives on US Democratization Efforts: From the Outside in (Palgrave Macmillan), p. 125

Centre for Arab Unity Studies (2012) 'Arab public opinion towards Arab unity'. Centre for Arab Unity Studies, Beirut, Unpublished report

Červenka, Zdenek (1974), 'The Emergence and Significance of the AfricanArab Solidarity', Instant Research on Peace and Violence 4(2), pp. 102-109 
Colin, Legum (1962), Pan-Africanism: A Short Political Guide (Frederick A. Praeger Publishers)

Constitution of The Tunisian Republic (2014), Articles 5\&39 Translated and printed by: Jasmine Foundation - Tunisia. Available at: www.jasminefoundation.org (Accessed 28 March 2019)

Council on Foreign Relations (2012), 'Summary Report for workshop on Regional Cooperation in a New Middle East' Joint report by CFR's International Institutions and Global Governance program and the American University in Cairo's School of Global Affairs and Public Policy

Damidaz, Nima and Sorenson, Karl (2009), 'To have and have-not: A Study on the North African Regional Capacity', published by FOI, Swedish Defence Research Agency. Available at: http://www.asclibrary.nl/docs/370/138/370138384.pdf (Accessed 28 Mach 2019) Destradi, Sandra (2010), 'Regional Powers and Their Strategies: Empire, Hegemony and Leadership' Review of International Studies 36(4), pp. 903930

El Amrani, Issandr (2005), 'Cultural politics and cultural policy in the Arab world' in Cultural Policies in Algeria, Egypt, Jordan, Lebanon, Morocco, Palestine, Syria and Tunisia (Boekmanstudies)

Elhag, Assim (2012), 'The Sudanese Role in Libya 2011', World Peace Foundation. Available at:

https://sites.tufts.edu/reinventingpeace/2012/12/17/the-sudanese-rolein-libya-2011/ (Accessed 28 March 2019)

El-Khawas, Mohamed (1975), 'Africa and the Middle Eastern Crisis', African Issues 5(1), pp. 33-42.

El-Mahdi, Rabab and Philip, Marfleet (2009), Egypt: The Moment of Change (Zed Books)

European External Action Service (2017), Meeting of the Libya Quartet: Joint Communiqué. Available at: https://eeas.europa.eu/headquarters/headquartershomepage en/26764 LMeeting\%20of\%20the\%20Libya\%20Quartet:\%20Joint\%20Communiqu \%C3\%A9 (Accessed 28 March 2019) 
Gilpin, Robert (1981), War and Change in World Politics (Cambridge University Press)

Global Fire Power (2016), 'African Powers Ranked by Military Strength Ranking'. Available at: http://www.globalfirepower.com/countrieslisting-africa.asp (Accessed: 28 March 2019)

Gordan, Murray (1998), Slavery in the Arab World (New Amsterdam Books)

Gramsci, Antonio (1995), Further Selections from the Prison Notebooks (University of Minnesota Press)

Grint, Keith (2010), Leadership: A Very Short Introduction (Oxford University Press)

Gumbo Bekezela (2014), 'The Hobbesian Nightmare in the Arab League: A Collision of Identity Politics and National Interests in Middle East Conflicts', Journal of Political Science and Public Affairs 2(4)

Haseb, Khalid (1984), The Arabs and Africa (Croom Helm: London)

Hassouna, Hussien (1975), The League of Arab States and Regional Disputes (Oceana Publication: New York)

Huliaras, Asteris (2001), 'Qadhafi's comeback: Libya and sub-Saharan Africa in the 1990s', African Affairs 100(398), pp. 5-25

Hurrell, Andrew (2005), Hegemony and Regional Governance in the Americas. In Regionalism and Governance in the Americas (Palgrave Macmillan UK)

Jacob, Abel (1971), 'Israel's Military Aid to Africa, 1960-66', The Journal of Modern African Studies 9(2), pp.165-187

Kasaija, Phillip Apuuli (2013), 'The African Union (AU), the Libya Crisis and the notion of 'African solutions to African problems', Journal of Contemporary African Studies 31(1), pp. 117-138

Kindleberger, Charles (1973), Charles The World in Depression 1929-1939 (University of California Press Berkely) 
Levey, Zach (2003), 'The Rise and Decline of a Special Relationship: Israel and Ghana 1957-1966', African Studies Review 46(1), pp.155-177

Levey, Zach (2008), 'Israel's Exit from Africa, 1973: The Road to Diplomatic Isolation', British Journal of Middle Eastern Studies 35(2), pp.205-226

Mazrui, Ali (1977), Africa's International Relations, The Diplomacy of Dependency and Change (Heinemann; Westview Press London)

Mazru, Ali (1979), 'Africa and the Arab-Israeli conflict' in Historical and Socio-cultural Relations Between Black Africa and the Arab World from 1935 to the Present (UNESCO Publication)

Mboya, Tom (1963), Freedom and After (Andre Deutsch: London)

Miller, Jake (1975), 'African-Israeli relations: Impact on continental unity', Middle East Journal 29(4), pp. 393-408

Morroco World News (2011), Morocco confirms recognition of Libyan Transitional Council. Available At: https://www.moroccoworldnews.com/2011/08/7536/moroccoconfirms-recognition-of-libyan-transitional-council/7536/ (Accessed 28 March 2019)

Nadelmann, Ethan (1981), 'Israel and Black Africa: A Rapprochement?', The Journal of Modern African Studies 19(2), pp. 183-219.

Nantambu, Kwame (1998), 'Pan-Africanism Versus Pan-African Nationalism: An Afrocentric Analysis', Journal of Black Studies 28(5), pp. 561-574

Northouse, Peter (2015), Leadership: Theory and Practice (Sage publications)

Obala, Luke (2011), 'Africa and the Arab World after Gaddafi',Al Jazeera Centre for Studies

Obeidi, Amal (2011), Political Culture in Libya (Psychology Press)

Ouidyane, Elouardaoui (2014), Behind the Scenes of Pan-Arabism (Glänta Eurozine) 
Peters, Joel (1992), Israel and Africa: The Problematic Friendship (IB Tauris)

Polakow-Suransky, Sasha (2010), The unspoken alliance: Israel's secret relationship with Apartheid South Africa (Jacana Media)

Putnam, Robert (1988), 'Diplomacy and Domestic Politics: The Logic of Two-level Games' ,International Organizations 42(3), pp. 427-460

Tawfik, Rawia (2016), 'Egypt and the Transformations of the Pan-African Movement: The Challenge of Adaptation', African studies 75(3), pp. 297315

Raven, Bertram and French, John R. P. (1958), 'Legitimate Power, Coercive Power, and Observability in Social Influence' Sociometry 21(2), pp. 83-97

Roberts, Hugh (2011), 'Who said Gaddafi had to go?', London Review of Books 33(22), pp. 8-18

Rogin, Josh (2017), 'Over 200 Arab groups call for Libya no-fly zone', Foreign Policy. Available at: https://foreignpolicy.com/2011/02/25/over200-arab-groups-call-for-libya-no-fly-zone/ (Accessed 28 March 2019)

Salem, Ahmed (2011), The Myth and Reality of the North Africa versus Sub-Saharan Split in the Nile Basin in Regional Integration in Africa Bridging the North-Sub-Saharan Divide Hassan, Hamdy (ed) (African Books Collective)

Sawani, Youssef (2012), 'The End of Pan-Arabism' Revisited: Reflections on the Arab Spring', Contemporary Arab Affairs 5(3), pp. 382-397

Sengupta, Kim (2011), 'Rebels settle scores in Libyan capital', The Independent. Available at:

http://www.independent.co.uk/news/world/africa/rebels-settle-scoresin-libyan-capital-2344671.html (Accessed 29 March 2019)

Siba, Grovogui (2011), 'Looking Beyond Spring for the Season: An African Perspective on the World Order after the Arab Revolt', Globalizations 8(5), pp. 567-572 
Sirriyeh, Hussien (2000) 'A New Version of Pan-Arabism?', Journal of International Relations 15(3), pp. 53-66

Sharawy, Helmy (2014), 'Arab-African relations from Liberation to Globalisation', African Renaissance 1(1), pp. 43-54

Temlali, Yassine (2012), 'The "'Arab Spring" Rebirth or Final Throes of Pan-Arabism? Perspectives', Contemporary Arab Affairs 5(3), pp. 382-397

Tran, Mark (2011), 'Libyan Rebels Protest over African Union Peace Mission 'The Guardian. Available at:

https://www.theguardian.com/world/2011/apr/11/libya-rebels-protestpeace-mission (Accessed 28 March 2019)

UNSC (2011), 'United Nations Security Council Resolution 1973 (2011) on Libya'. Available at

https://www.nato.int/nato static/assets/pdf/pdf 2011 03/20110927 11 0311-UNSCR-1973.pdf (Accessed 28 March 2019)

UNIMSAL (2016), EU, AU, Arab League and United Nations Joint Communique on Libya - 22 Sept. 2016. Available at https://unsmil.unmissions.org/joint-communique-libya, United Nations Support Mission In Libya (Accessed 28 March 2019)

Vandewalle, Dirk (2012), A History of Modern Libya (Cambridge University Press)

Wai, Dunstan (1983), 'African-Arab Relations: Interdependence or Misplaced Optimism?', The Journal of Modern African Studies 21(02), pp. 187-213

Warner, Jeroen (2008), 'Contested hydro-hegemony/hydraulic control and security in Turkey', Water Alternatives 1(2), pp. 271-288

World Bank (2011), World Bank Indicators Database Gross domestic product 2010. Available at:

https://siteresources.worldbank.org/DATASTATISTICS/Resources/GDP.p df (Accessed 28 March 2019)

Woronoff, Jon (1970), Organizing African Unity (Scarecrow Press, New Jersey), p. 138 
Leadership and Developing Societies

Vol 3 No1, pp. 1-32

DOI: https://doi.org/10.47697/lds.3436100

Yukl, Gary A. (1981), Leadership in organizations (Pearson Education India)

Yin, Robert (1984), Case Study Research, Design and Methods (Sage Publications) 